\title{
Cocksfoot pasture production in relation to environmental variables
}

\author{
A. MILLS, D.J. MOOT and B.A. MCKENZIE \\ Agriculture and Life Sciences Division, PO Box 84, Lincoln University, Canterbury \\ moot@lincoln.ac.nz
}

\begin{abstract}
The effects of temperature, water and nitrogen on pasture production of an 8 year old 'Wana' cocksfoot pasture were quantified at Lincoln University, Canterbury. The maximum dry matter (DM) yield was $22.0 \mathrm{t} / \mathrm{ha} / \mathrm{yr}$ when neither water nor $\mathrm{N}$ were limiting. Crude protein yield of $+\mathrm{N}$ pastures was 3.2-4.2 $\mathrm{t} / \mathrm{ha} / \mathrm{yr}$ compared with $1.0 \mathrm{t} / \mathrm{ha}$ in $-\mathrm{N}$ pastures. Metabolisable energy averaged $178^{*} 10^{3} \mathrm{MJ} \mathrm{ME} / \mathrm{ha} / \mathrm{yr}$ for the $+\mathrm{N}$ pastures compared with $69^{*} 10^{3} \mathrm{MJ} \mathrm{ME} / \mathrm{ha} / \mathrm{yr}$ for $-\mathrm{N}$ pastures. Seasonal differences in pasture production were explained in relation to thermal time with $7.0 \mathrm{~kg}$ $\mathrm{DM} /{ }^{\circ} \mathrm{Cd}$ for $\mathrm{N}$ fertilised pastures and $3.3 \mathrm{~kg} \mathrm{DM} /{ }^{\circ} \mathrm{Cd}$ when no $\mathrm{N}$ was applied. During periods of water stress, relative yield decreased at a rate of $1.4 \% / \mathrm{mm}$ when the soils critical limiting deficit of $78 \mathrm{~mm}$ was exceeded.
\end{abstract}

Keywords: Dactylis glomerata, irrigation, nitrogen, thermal time.

\section{Introduction}

Cocksfoot (Dactylis glomerata) is the second most commonly sown pasture grass in New Zealand. It is recommended for low to moderate fertility, summer dry regions (Rumball 1982; Baker et al. 1985) and its ability to produce, survive and persist when subjected to drought (Stevens et al. 1992) makes it an important component in most dryland pastures. Annual DM yields of cocksfoot in Canterbury range from $\sim 7$ to $>28 \mathrm{t} \mathrm{DM} /$ ha (Stevens et al. 1992; Peri et al. 2002a). The lower value represents a typical yield under grazed dryland conditions and the upper extreme was the environmental maximum when neither water nor nitrogen limited pasture growth.

In this study, the aim was to quantify the relationship between pasture growth and the main environmental variables of temperature, nitrogen and moisture. Once established, the potential impact of limitations in any one factor can be assessed for different environments and mitigation strategies to overcome production losses developed. Of these factors, temperature induces a seasonal effect that cannot be manipulated through management. However, the impact can be quantified in relation to thermal time and responses predicted. The aggressive growth habit of cocksfoot, compared with legumes such as white clover (Trifolium repens), leads to a decrease in the clover component (Lee and Cho 1985; Moloney 1991). This causes nitrogen deficient pastures with restricted leaf photosynthesis (Peri et al. $2002 \mathrm{~b}$ ) and decreased pasture grazing preference (Edwards et al. 1993).

\section{Materials and Methods}

The experiment was conducted at Lincoln University, Canterbury on a Templeton silt loam soil overlying alluvial gravels (Cox 1978). The site was sown in March 1995 with 'Grasslands Wana' cocksfoot and white, red ( $T$. pratense) or subterranean ( $T$. subterraneum) clovers but by the beginning of this experiment in September 2003 clover was $<2 \%$ of total dry matter (DM). Prior to the experiment, lime was applied at $5.0 \mathrm{t} / \mathrm{ha}$ and superphosphate at $400 \mathrm{~kg} / \mathrm{ha}$. Following annual soil test results, potassium sulphate was applied at $100 \mathrm{~kg} / \mathrm{ha}$ in October 2004.

The split plot experiment with three replicates used Irrigation (I) or Dryland (D) main plots $(12.0 \times 12.6 \mathrm{~m})$ and nitrogen $(\mathrm{N})(+\mathrm{N}$ or $-\mathrm{N})$ as subplots $(6.0 \times 6.3 \mathrm{~m})$ for 2 years from September 2003. In 2003/04, $800 \mathrm{~kg} \mathrm{~N} /$ ha was applied as urea $(46 \% \mathrm{~N})$ in eight applications of $100 \mathrm{~kg} \mathrm{~N} / \mathrm{ha}$ at the beginning of active regrowth periods. Applications were made in conjunction with rainfall or irrigation to ensure maximum efficiency. In 2004/05, the $\mathrm{N}$ rate was $1600 \mathrm{~kg} \mathrm{~N} / \mathrm{ha} / \mathrm{y}$ in 11 split applications.

Regrowth periods were 25-35 days during active growth and up to a maximum of 52 days over winter. Dry matter was measured from a $0.2 \mathrm{~m}^{2}$ quadrat and plots were mown (cut and carry) to a residual of $30 \mathrm{~mm}$ at the end of each rotation. Botanical composition was measured at each harvest before samples were dried at $50-60^{\circ} \mathrm{C}$. Green cocksfoot material, including reproductive tillers when present, was analysed for metabolisable energy (ME) and $\mathrm{N}$ content (\%). The yields and $\mathrm{N} \%$ of the $\mathrm{I}+\mathrm{N}$ pastures were used as an indicator of the non limited potential of the pasture.

Annual average rainfall was $624 \mathrm{~mm}$, with a mean annual temperature of $11^{\circ} \mathrm{C}$ as recorded at the Broadfields meteorological station. Daily mean air temperatures were used to calculate thermal time $(\mathrm{Tt})$ accumulation with a base temperature of $3^{\circ} \mathrm{C}$ and an optimum temperature of $24^{\circ} \mathrm{C}$. Total rainfall was 515 $\mathrm{mm}$ in year 1 compared with $523 \mathrm{~mm}$ in year 2 . Similarly, annual potential evapotranspiration (PET) was $1109 \mathrm{~mm}$ and $1052 \mathrm{~mm}$ in each year. Within this environment, PET usually exceeds rainfall from September to April. The mean annual long term potential 
soil moisture deficit is $400 \mathrm{~mm}$ compared with $650 \mathrm{~mm}$ in year 1 and $625 \mathrm{~mm}$ in year 2 .

Soil moisture was monitored by Time Domain Reflectometry (TDR) and neutron probe every 7-14 d. Flow meters measured the amount of water applied to irrigated plots with $447 \mathrm{~mm}$ of water applied by overhead sprinklers in 2003/04 and $256 \mathrm{~mm}$ in 2004/05. Water was consistently extracted from $0.0-0.8 \mathrm{~m}$ in all plots so the actual soil moisture deficit was determined to this depth. The critical limiting deficit was the actual soil moisture deficit at which the relative yield of the dryland treatments declined compared with the fully irrigated pasture (Penman 1971).

Results were analysed (GenStat 8.2) using the repeated measure technique. Temperature adjusted growth rates were derived by regression, through the origin, of accumulated DM against accumulated thermal time. The critical limiting soil water deficit, specific to this soil/pasture combination, was determined by broken stick models for dryland data. The annual and seasonal yields of $+\mathrm{N}$ and $-\mathrm{N}$ treatments differed. Therefore, the relative yield for the two dryland treatments had to be determined separately with 1) I+N used as the potential for the $\mathrm{D}+\mathrm{N}$ treatment and 2) I-N used as the water non limited maximum for the D-N treatment. The temperature adjusted growth rates $(\mathrm{kg}$ $\mathrm{DM} /{ }^{\circ} \mathrm{Cd}$ ) of dryland pastures were compared with irrigated pastures by ANOVA of slopes against thermal time for pre- and post water stress periods across all treatments.

\section{Results}

There was a three way interaction $(\mathrm{P} \leq 0.05)$ between irrigation, nitrogen and year $\left(\mathrm{I}^{*} \mathrm{~N} * \mathrm{Y}\right)$ for total annual DM yield (Table 1). Total treatment yields were similar between years for the $\mathrm{I}+\mathrm{N}$, I-N and $\mathrm{D}+\mathrm{N}$ pastures. However, D-N treatments produced more DM in 2003/
04 than in 2004/05. There was an $\mathrm{N}^{*} \mathrm{Y}$ interaction $(\mathrm{P} \leq 0.001)$ which resulted from a $30 \%$ increase in annual CP yield ( $\mathrm{tCP} /$ ha) between 2003/04 and 2004/05 from $+\mathrm{N}$ pastures but no increase in $-\mathrm{N}$ treatments. Annual ME yield was also affected by an $\mathrm{N}^{*} \mathrm{Y}$ interaction $(\mathrm{P} \leq 0.01)$ with similar values for the $-\mathrm{N}$ pastures in 2003/04 and 2004/05 but a 7\% increase for $+\mathrm{N}$ pastures between 2003/04 and 2004/05. Over the 2 years, ME of green cocksfoot herbage ranged from 10.2 - 12.4 MJ ME/kg DM.

Mean daily growth rates of $\mathrm{I}+\mathrm{N}$ pastures increased from a minimum of $10 \mathrm{~kg} \mathrm{DM} / \mathrm{ha} / \mathrm{d}$ in winter to $>100 \mathrm{~kg}$ $\mathrm{DM} / \mathrm{ha} / \mathrm{d}$ in summer in both years (Fig. 1). The I-N pastures also showed the lowest growth rates in winter but maximum growth rates occurred earlier in the growing season and were at least $50 \%$ less than those of the $\mathrm{I}+\mathrm{N}$ pastures. There were $\mathrm{I}^{*} \mathrm{~N}$ interactions observed in summer caused by decreased growth rates in dryland pastures.

To explain the seasonal variations in pasture growth rates the effect of temperature was summarised (Fig. 2) through accumulated thermal time (Moot et al. 2000). The temperature adjusted growth rate of the $\mathrm{I}+\mathrm{N}$ pastures increased $(\mathrm{P} \leq 0.001)$ at $7.2 \mathrm{~kg} \mathrm{DM} /{ }^{\circ} \mathrm{Cd}$ above the base temperature. For I-N pastures the rate was 3.2 $\mathrm{kg} \mathrm{DM} /{ }^{\circ} \mathrm{Cd}$ or $56 \%$ lower than that of $\mathrm{I}+\mathrm{N}$ pastures. For both treatments there was an indication of systematic variation around the regression which suggested an overestimation of DM production in autumn/winter and underestimated production in spring/summer.

The difference between temperature adjusted growth rates of $\mathrm{I}+\mathrm{N}$ and $\mathrm{I}-\mathrm{N}$ pastures was quantified by the ratio between actual $\mathrm{N} \%$ and optimum $\mathrm{N}$ content (Lemaire et al. 1989). The $-\mathrm{N}$ pastures were consistently $\mathrm{N}$ deficient, with about $50 \%$ of the $\mathrm{N}$ content of fertilised treatments, and $\mathrm{D}+\mathrm{N}$ pastures were $\mathrm{N}$ deficient in summer.

Table 1 Total annual dry matter (DM) production, annual \% dead material, crude protein (CP) yield (t/ha/yr) and annual metabolisable energy (ME) yield (GJ/ha) of a 'Wana' cocksfoot monoculture grown at Lincoln University, Canterbury, New Zealand in 2003/04 and 2004/05.

\begin{tabular}{clccc}
\hline Year $(\mathrm{Y})$ & Treatment & Total DM (t/ha) & Annual CP (t/ha) & Annual ME $\left(\mathrm{MJ} / \mathrm{ha}^{*} 10^{3}\right)$ \\
\hline \multirow{2}{2003/04}{} & $\mathrm{I}+\mathrm{N}$ & 22.6 & 3.7 & 202 \\
& $\mathrm{I}-\mathrm{N}$ & 10.5 & 1.2 & 91 \\
& $\mathrm{D}+\mathrm{N}$ & 15.1 & 2.7 & 143 \\
& $\mathrm{D}-\mathrm{N}$ & 7.5 & 0.6 & 53 \\
$2004 / 05$ & $\mathrm{I}$ & 21.2 & 4.7 & 204 \\
& $\mathrm{I}-\mathrm{N}$ & 9.1 & 1.3 & 86 \\
& $\mathrm{D}+\mathrm{N}$ & 16.4 & 3.8 & 161 \\
& $\mathrm{D}-\mathrm{N}$ & 5.0 & 0.6 & 45 \\
& Effect & $\mathrm{I}^{*} \mathrm{~N}^{*} \mathrm{Y}$ & $\mathrm{N}^{*} \mathrm{Y}$ & $\mathrm{N}^{*} \mathrm{Y}$ \\
& Significance & ${ }^{*}$ & 0.2 & 10.0 \\
\hline
\end{tabular}

Note: Levels of significance are: $\left.0.05\left(^{*}\right), 0.01{ }^{(\star}\right)$, and $\left.0.0011^{(\star \star}\right)$. 
Figure 1 Daily growth rates of 'Wana' cocksfoot monocultures under I+N (○), I-N (O), D+N ( $\nabla)$ and D-N ( $\nabla)$ treatments. Error bars are maximum SEM for any sampling date for (a) I effects, (b) N effects or (c) $\mathrm{I}^{*} \mathrm{~N}$ interactions.

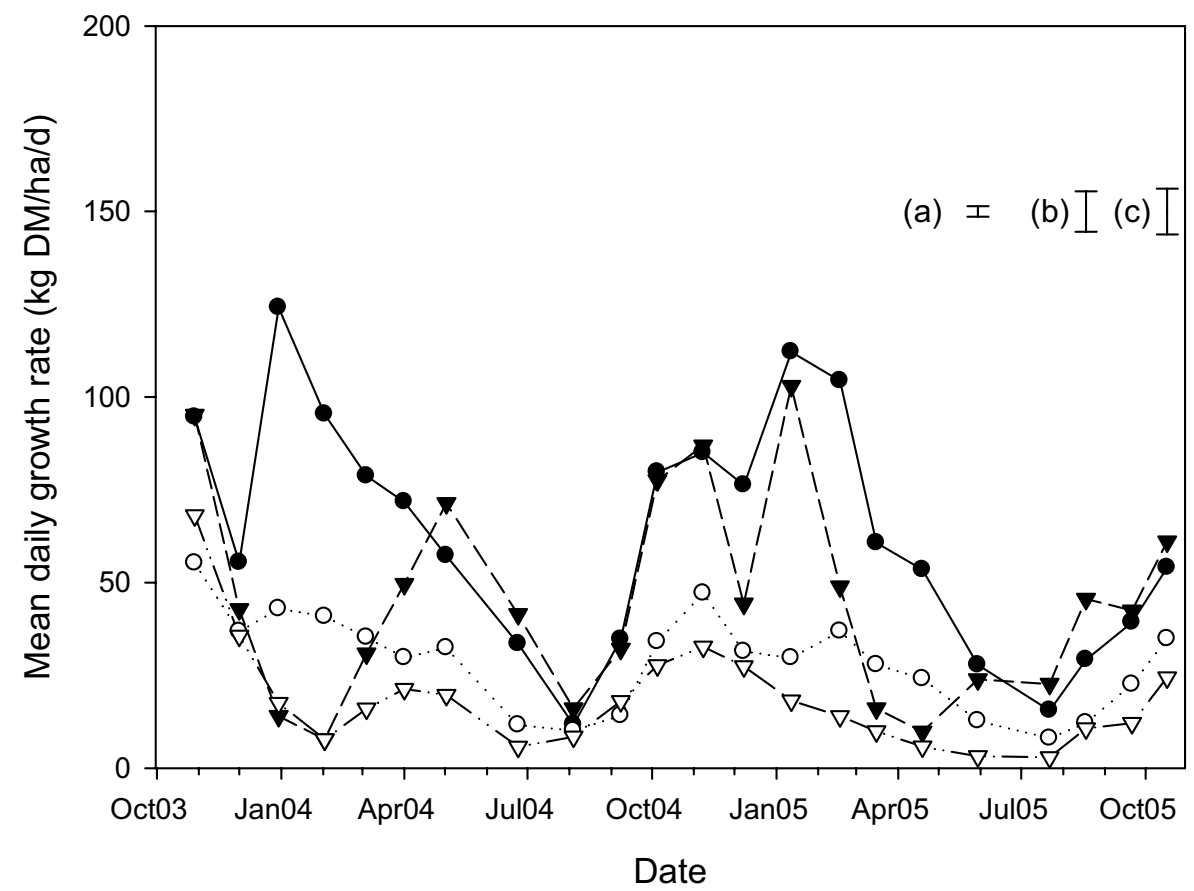

Figure 2 Dry matter (DM) accumulation in 2003/04 (closed symbols) and 2004/05 (open symbols) of I+N (0,O) and I-N $(\boldsymbol{\nabla}, \nabla)$ pastures against accumulated thermal time $(\mathrm{Tt})$ with a base temperature of $3^{\circ} \mathrm{C}$ for a 'Wana' cocksfoot monoculture at Lincoln University, Canterbury New Zealand. Regression of $\mathrm{I}+\mathrm{N}$ is $y=7.2 \pm$ SE $0.1 \times\left(R^{2}=0.97\right)$ and $\mathrm{I}-\mathrm{N}$ is $\mathrm{y}=3.2 \pm \mathrm{SE} 0.1 \times\left(\mathrm{R}^{2}=0.95\right)$ with standard error of the slope is given for each regression. Arrows indicate the range over which the pasture contained reproductive tillers and corresponds to calendar days between 1 December and 15 January.

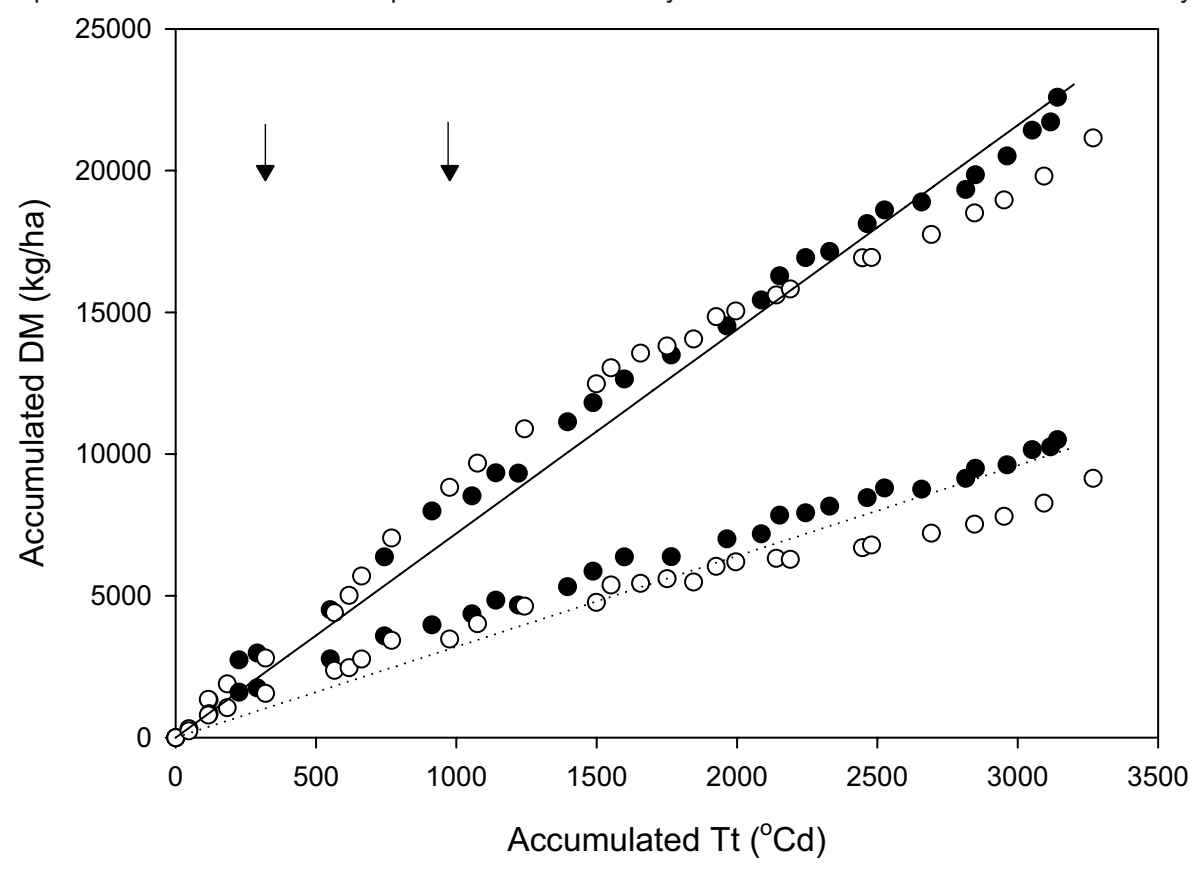


Figure 3 Decrease in relative yield of (a) D+N ( $\nabla)$ relative to $I+N(\bullet)$ and (b) D-N ( $\nabla)$ relative to I-N (O) for 'Wana' cocksfoot pasture at Lincoln University, Canterbury, New Zealand during periods when the actual soil moisture deficit was increasing.

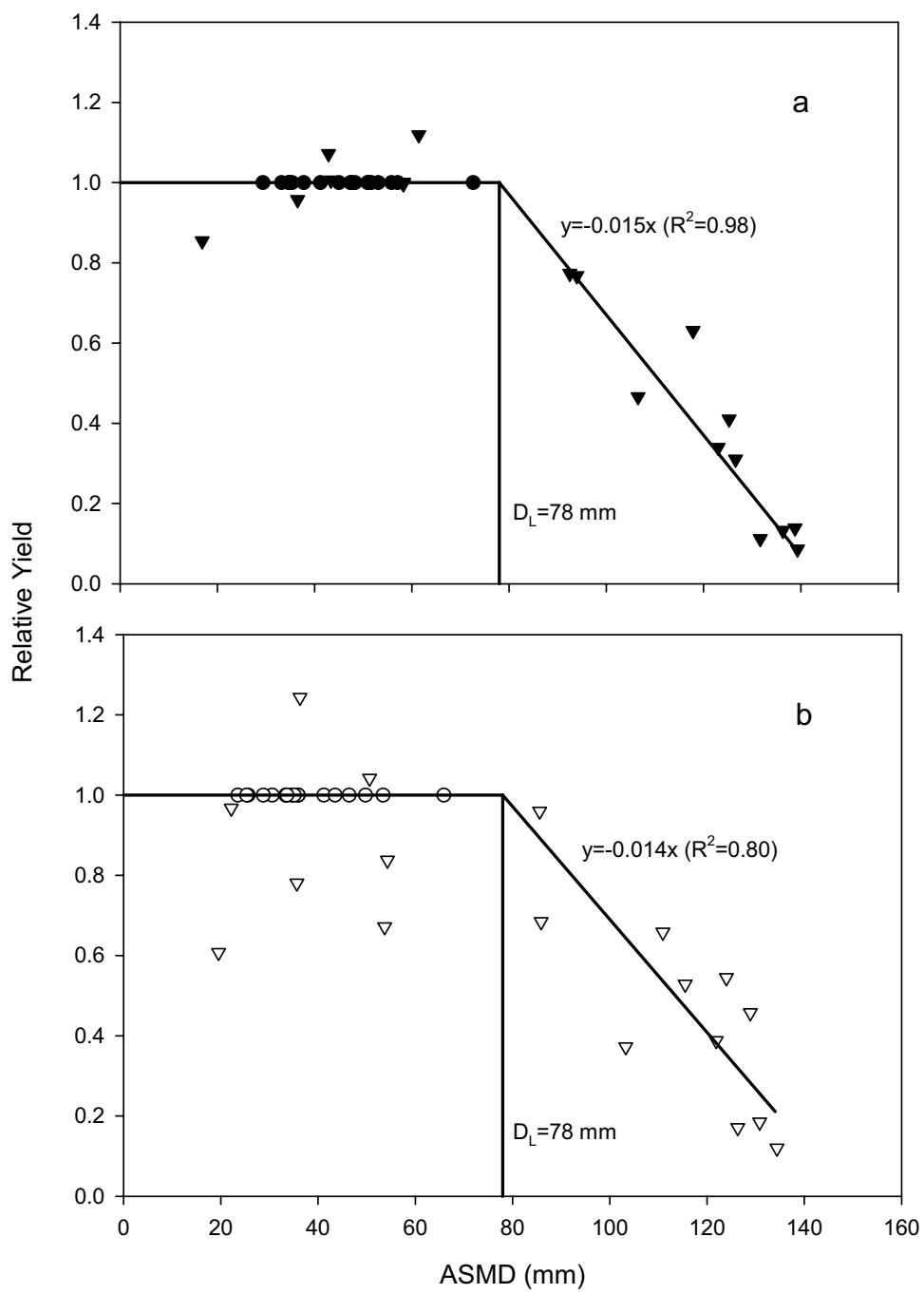

The actual soil moisture deficit $(0-0.8 \mathrm{~m})$ reached a maximum of $\sim 140 \mathrm{~mm}$ in 2003/04 and $\sim 130 \mathrm{~mm}$ in $2004 / 05$. The critical limiting deficit was averaged across treatments to $78 \mathrm{~mm}$ with the rate of reduction in relative yield constant at $1.45 \% / \mathrm{mm}$. Thus, despite a 2 month difference in the timing of maximum actual soil moisture deficit between years, the critical limiting deficit was comparable and the response of DM production when this was exceeded was similar.

\section{Discussion}

The maximum yield attained within this environment was $22.0 \mathrm{t} \mathrm{DM} /$ ha (Table 1 ). When no $\mathrm{N}$ was applied (I-N) yields were less than $50 \%$ of this potential. Dryland pastures supplied with non limiting $\mathrm{N}$ produced $72 \%$ of the yield of the $\mathrm{I}+\mathrm{N}$ pasture showing the major impact of $\mathrm{N}$ availability on cocksfoot production. This confirms previous work which showed $\mathrm{N}$, rather than water, was the factor most limiting cocksfoot production (Peri et al. 2002a). When no irrigation or $\mathrm{N}$ were applied, yields were only $25 \%$ of the environmental potential and similar to previous results (Stevens et al. 1992). In addition, $\mathrm{N}$ was the main factor influencing pasture quality parameters (Table 1). Reports of low cocksfoot pasture quality and associated poor preference (Edwards et al. 1993) may reflect increased proportions of senesced and/or diseased leaf material of low $\mathrm{N}$ content relative to total DM.

To extrapolate results to other environments, the relationship between pasture production and the main 
Figure 4 Dry matter production of D+N pastures in (a) 2003/04 and (b) 2004/05 and D-N pastures in (c) 2003/ 04 and (d) 2004/05. Solid lines shown by * and ${ }^{* *}$ represent temperature adjusted growth rates of $\mathrm{I}+\mathrm{N}$ $(y=7.2 x)$ and I-N $(y=3.2 x)$ as shown in Figure 2. Dashed vertical lines represent the period during which the critical limiting deficit $(78 \mathrm{~mm})$ was exceeded by dryland pastures. Temperature adjusted growth rates of dryland pastures, excluding the drought period, were 7.0 and $3.3 \mathrm{~kg} \mathrm{DM} /{ }^{\circ} \mathrm{Cd}$ for $\mathrm{D}+\mathrm{N}$ and $\mathrm{D}+\mathrm{N}$ pastures, respectively.
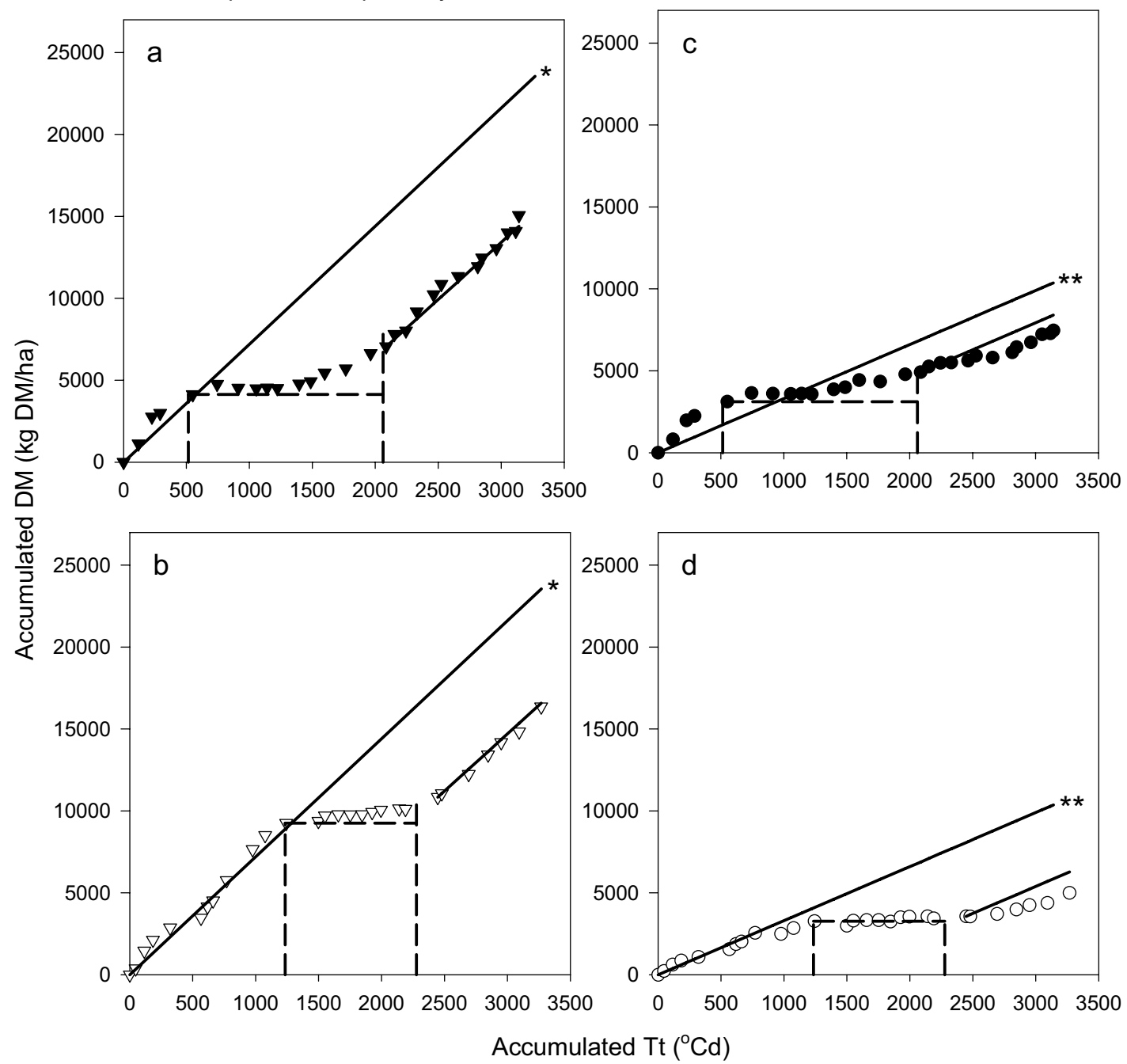

environmental drivers were derived. The seasonal variation in growth rates was accounted for using thermal time, where the $\mathrm{I}+\mathrm{N}$ pasture had a temperature adjusted growth rate double that of I-N pastures (Fig. 2). Thus, at any given temperature, when moisture was non-limiting, the $\mathrm{I}+\mathrm{N}$ pastures produced $\mathrm{DM}$ at twice the rate of the I-N or control pastures. The difference between temperature adjusted growth rates of $\mathrm{I}+\mathrm{N}$ and $\mathrm{I}-\mathrm{N}$ pastures was due to $\mathrm{N}$ content. Leaf $\mathrm{N}$ concentrations between $4.0-5.9 \%$ do not limit photosynthesis whereas it is almost halved when leaf $\mathrm{N}$ is between $1.5-4.0 \%$ (Peri 2002) as found in the $-\mathrm{N}$ pastures.
The effect of water stress for $\mathrm{D}+\mathrm{N}$ and $\mathrm{D}-\mathrm{N}$ pastures was examined separately. Beyond the critical limiting deficit of $78 \mathrm{~mm}$, relative yield decreased at a constant rate of $1.45 \% / \mathrm{mm}$ (Fig. 3). Therefore, at any given actual soil moisture deficit, the extent of yield reductions below potential can be quantified. For example, at an actual soil moisture deficit of $100 \mathrm{~mm}$ yield would be $32 \%$ below potential. In $2003 / 04$, the $\mathrm{D}+\mathrm{N}$ pastures were water stressed during the period between 465 $2062^{\circ} \mathrm{Cd}$ (Fig. 4). This corresponded to the calendar dates of 21/11/2003-30/3/2004. In D-N pastures, water stress compromised DM production between 515 to $2062^{\circ} \mathrm{Cd}$, or from $1 / 12 / 2003$ to $30 / 3 / 2004$. In $2004 / 05$, 
December 2004 rainfall caused two separate periods of water stress. The first occurred between $320-550^{\circ} \mathrm{Cd}(8 /$ $11 / 2004-1 / 12 / 2004)$ and the second occurred between $1243-2278^{\circ} \mathrm{Cd}(31 / 1 / 2005-1 / 5 / 2005)$.

Based on the known periods of water stress, the potential yield loss due to insufficient water was estimated, from temperature adjusted growth rates, to be 11.5 and $9.1 \mathrm{t} / \mathrm{ha}$ for $\mathrm{D}+\mathrm{N}$ pastures compared with 4.9 and $4.0 \mathrm{t} /$ ha for D-N pastures in 2003/04 and 2004/05. Rainfall during the deficit period is available for growth even if it does not appear to increase the actual soil moisture deficit to $<78 \mathrm{~mm}$. As a result DM produced within the deficit period was subtracted from the estimated yield loss. This decreased the variation between estimated and actual yields to within 1\% for $\mathrm{D}+\mathrm{N}$ pastures and within $4-12 \%$ of measured DM yield for D-N pastures.

Data were then reanalysed by ANOVA to compare temperature adjusted growth rates of all pastures during periods when water was not the main limitation to DM production (Fig. 4). These results showed $\mathrm{N}$ deficiency caused $(P \leq 0.001)$ the main differences in the temperature adjusted growth rates. The $+\mathrm{N}$ pastures produced $7.0 \mathrm{~kg} \mathrm{DM} /{ }^{\circ} \mathrm{Cd}$ compared with $3.3 \mathrm{~kg} \mathrm{DM} /$ ${ }^{\circ} \mathrm{Cd}$ for $-\mathrm{N}$ pastures. These values show that the rate of $\mathrm{DM}$ accumulation prior to reaching the critical limiting deficit, and then after rainfall alleviated water stress, were comparable to those calculated under non limiting moisture conditions for the $\mathrm{I}+\mathrm{N}$ and $\mathrm{I}-\mathrm{N}$ pastures (Fig. 2).

If there is no water for growth, regardless of pasture species, no growth will occur. The main objective in a dryland system regularly subjected to summer water stress is to ensure the sown pasture can persist through, and recover after, experiencing drought conditions. This study confirms the importance of cocksfoot in summer dry regions and shows that yield can be improved by increased $\mathrm{N}$ fertility. The rates of $\mathrm{N}$ applied in this study are not recommended for commercial use. It is important to identify a legume which can survive and persist in a mixture with cocksfoot to alleviate the main yield constraint of $\mathrm{N}$ deficiency and the associated reduction in pasture quality (Lee and Cho 1985; Moloney 1991; Edwards et al. 1993).

\section{ACKNOWLEDGEMENTS}

A. Mills acknowledges AGMARDT, Lincoln University, the Cocksfoot Growers Association and the Sinclair Cummings Trust for financial assistance during her PhD study.

\section{REFERENCES}

Baker, D.J.; Lancashire, J.A. and Meurk, C. 1985.

'Grasslands Wana' cocksfoot - an improved grass suitable for hill country. Proceedings of the New Zealand Grassland Association 46: 167-172.

Cox, J.E. 1978. Soils and agriculture of Paparua County, Canterbury, New Zealand. New Zealand Soil Bureau Bulletin, 34.

Edwards, G.R.; Lucas, R.J. and Johnston, M.R. 1993. Grazing preference for pasture species by sheep is affected by endophyte and nitrogen fertility. Proceedings of the New Zealand Grassland Association 55: 137-141.

Lee, H.J. and Cho, M.J. 1985. Root competition and productivity in mono- and binary association of four forage species. pp 663-665 In: Proceedings of the XV International Grassland Congress, August 24-31, Kyoto, Japan.

Lemaire, G.; Gastal, F. and Salette, J. 1989. Analysis of the effect of $\mathrm{N}$ nutrition on dry matter yield of a sward by reference to potential yield and optimum $\mathrm{N}$ content. pp. 179-180. In: Proceedings of the XVI International Grassland Congress, 4-11-October 1989, Nice, France.

Moloney, S.C. 1991. Performance of tall fescue, cocksfoot and phalaris compared with perennial ryegrass, in on-farm trials. Proceedings of the New Zealand Grassland Association 53: 41-46.

Moot, D.J.; Scott, W.R.; Roy, A.M. and Nicholls, A.C. 2000. Base temperature and thermal time requirements for germination and emergence of temperate pasture species. New Zealand Journal of Agricultural Research 43: 15-25.

Penman, H.L. 1971. Irrigation at Woburn - VII. Report for the Rothamsted Experimental Station 1970, Part 2, pp 147-170.

Peri, P.L. 2002. Leaf and canopy photosynthesis models for cocksfoot (Dactylis glomerata L.) grown in a silvopastoral system. PhD thesis, Lincoln University, Canterbury, New Zealand.

Peri, P.L.; Moot, D.J. and Lucas, R.J. 2002a. Urine patches indicate yield potential of cocksfoot. Proceedings of the New Zealand Grassland Association 64: 73-80.

Peri, P.L.; Moot, D.J.; McNeil, D.L.; Varella, A.C. and Lucas, R.J. 2002b. Modelling net photosynthetic rate of field-grown cocksfoot leaves under different nitrogen, water and temperature regimes. Grass and Forage Science 57: 61-71.

Rumball, W. 1982. 'Grasslands Wana' cocksfoot (Dactylis glomerata L.). New Zealand Journal of Experimental Agriculture 10: 51-52.

Stevens, D.R.; Baxter, G.S.; Stewart, A.; Casey, M.J. and Miller, K.B. 1992. Grasslands Kara cocksfoot: a productive cultivar under lax grazing. Proceedings of the New Zealand Grassland Association 54: 143146. 